\title{
Notice of fossil trees, near Gallipolis, Ohio
}

\section{Dr. S.P. Hildreth}

To cite this article: Dr. S.P. Hildreth (1827) Notice of fossil trees, near Gallipolis, Ohio, Philosophical Magazine Series 2, 2:10, 311-313, DOI: 10.1080/14786442708674401

To link to this article: http://dx.doi.org/10.1080/14786442708674401

曲 Published online: 10 Jul 2009.

Submit your article to this journal 준

Џ Article views: 3

Q View related articles $₫$ 
INDIGO COPPER-ORF.

Demselben has obtained from a specimen of this mineral from Hansbaden, specific gravity $\mathbf{3} 8$.

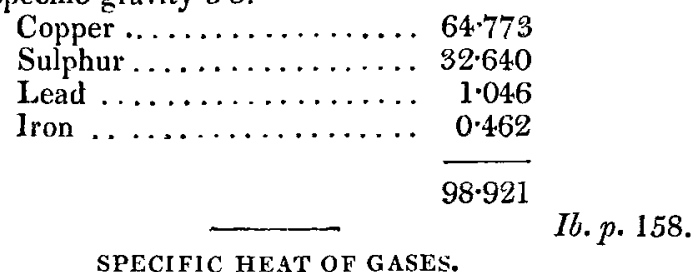

MM. Aug. de la Rive and F. Marcet having made numerous experiments on the above subject, have arrived at the following conclusions :-

1st, That equal volumes of all gases under the same constant pressure, have the same specific heat.

$2 \mathrm{dly}$, That all other circumstances being equal, the specific heat of all gases diminishes with diminished pressure, in a slightly converging series, and in a much less degree than that of the pressures.

$3 \mathrm{dly}$, That each gas has a different conducting power; that is to say, all gases have not the same power of communicating heat.-Ann. de Chim. et de Phys.

\section{COMPOSITION OF APATITE.}

Mons. G. Rosc remarks, that Berzelius having observed that the analyses of apatite by Klaproth and Vauquelin gave results which agreed with each other and also with definite proportions, he did not think it necessary to analyse it again. M. Rosc, however, finds that 100 parts of apatite from the following places, contained the annexed proportions of chloride and fluoride of calcium, - the remainder being phosphate of lime, with a small quantity of iron and magnesia in some cases, but quite accidental and unimportant.

\begin{tabular}{|c|c|c|c|}
\hline & & Chloride o & Sluoride of \\
\hline Apatite from & Snarum in Norway & $\begin{array}{c}\text { Calcium } \\
4.280\end{array}$ & $\begin{array}{c}\text { Calcium } \\
4 \cdot 590\end{array}$ \\
\hline & Cabo de Gata in Spain. $32: 5$ & $0 \cdot 885$ & $7 \cdot 049$ \\
\hline & Arendal & 0.801 & $7 \cdot 010$ \\
\hline & Greiner in the Tyrol & $0 \cdot 150$ & $7 \cdot 690$ \\
\hline & Faldigl in the Tyrol.. & $0 \cdot 100$ & $7 \cdot 620$ \\
\hline & Saint Gothard ..... & a trace & $7 \cdot 690$ \\
\hline & Ehrenfriedersdorf & ditto. & $\begin{array}{c}7 \cdot 690 \\
\text { lbid. }\end{array}$ \\
\hline
\end{tabular}

NOTICE OF FOSSIL TREES, NEAR GALLIPOLIS, OHIO; BY DR.

S. P. HILDRETH.

About two miles above Gallipolis, and half a mile from the Ohio river, is the location of several petrified trees. They are found near the base of a mural precipice of sandstone rock, 50 feet in height, and crowned with earth and trees to an elevation of 70 feet. 
From the foot of the rock, the ground gradually descends 30 or 40 feet to the Ohio bottom, which is low and swampy near the hill. This descent is probably made by the debris and earth rolling down from the hill, and gradually accumulating for ages, so as to cover a larger portion of the sandstone rock below the surface, than now appears above. The Ohio river no doubt once washed the base of the rock, but has gradually changed its channel to its present bed.

The rock in which the trees are imbedded, is a coarse sandstone, and they appear in the face of the rock at different elevations, some near the present surface of the ground, and others 4 or 5 feet above. They are 7 in number, and scattered through a space 80 rods in length; - some appear to have fallen, or been deposited with their tops, or branches, towards the river, and others in the opposite direction;--some came out of the reck obliquely, and others at right angles : they vary in diameter from 8 to is inches. I am not satisfied as to what family of trees they belong, but some of them look like elm. They are rendily distinguished from the rock in which they are imbedded, by their different colour and composition; their colour being much darker, and texture much harder; having a reddish-brown cast, like iron-ore, and so hard as to scintillate briskly, when struck with a hammer or head of an axe, affording evidence of their siliceous composition. The interstices of the laminæ are in some places filled with small crystals of quartz; and in others, with thin layers of stone coal. There is evidently a considerable quantity of iron in its composition, as the surface becomes quite red after being heated in the fire. The cortical part seems to have been more difficult to petrify than the ligneous portions, as it is in most of the trees readily separated from the wood and from the surrounding rock; being also easily broken, and resembling iron-rust in colour and appearance on some of the trees; and on others, like black sand or emery. The trees do not project much beyond the face of the rock, but appear to have been broken off at the same time when the rock was rent in which they are im. bedded. Sandstone is the principal rock formation throughout this part of the state of Ohio, forming mural precipices from 50 to 100 feet high, and in some places for half a mile, or a mile in extent, on the margins of the Ohio bottoms on both sides of the river, and underlying the river hills and country adjacent for a great distance; appearing near the beds of creeks and ravines, where the superincumbent earth has been washed away by the streams; but is seen no where to better advantage, than near the Ohio river. It is of various qualities ; micaceous, argillaceous and quartzose or siliceous; some so hard and compact as to make good mill-stones, and nearly resembling granite in colour and texture; and some so fine and close-grained as to bear the chisel of the sculptor nearly as well as marble. From the position of these fossil remains, I am led to conclude that the trees were brought to this spot by the water, at that remote period when the valley of the Ohio was an ocean, and covered in a vast bed of sand by some great convulsion of Nature. The sand in time became cemented into rock, and the spaces oc. 
cupied by the ligneous parts of the trees were, by infiltration, filled up with siliceous particles and iron, with some partial attempts at carbonization. Had there been a large pile of trees in a body, they would probably have formed stone coal, as is the case in the sand rock a few miles above; but this is only conjecture. There is a bed of stone coal in the same hill, not far from the trees. Native alum and copperas are also found in this vicinity.-Silliman's Journal, June 1827.

ON THE FASCINATION OF SNAKES; BY MR. NASH.

I have often heard stories about the power that snakes have to charm birds and animals, which, to say the least, I always treated with the coldness of scepticism, nor could I believe them until convinced by ocular demonstration. A case occurred in Williamsburgh, (Mass.) one mile south of the house of public worship, by the way side, in July last. As I was walking in the road at noon-day, my attention was drawn to the fence by the fluttering and hopping of a robin red-breast, and of a cat-bird, which upon my approach flew up, and perched on a sapling two or three rods distant; at this instant a large black snake reared his head from the ground near the fence. I immediately stepped back a little, and sat down upon an eminence; the snake in a few moments slunk again to the earth, with a calm placid appearance, and the birds soon after returned and lighted upon the ground near the snake : first stretching their wings upon the ground, and spreading their tails, they commenced fluttering around the snake, drawing nearer at almost every step, until they stepped near or across the snake, which would often move a little or throw himself into a different posture, apparently to seize his prey, which movements, Inoticed, seemed to frighten the birds, and they would veer off a few feet, but return again as soon as the snake was motionless. All that was wanting for the snake to secure the victims seemed to be, that the birds should pass near his head, which they would probably have soon done, but at this moment a waggon drove up and stopped. This frightened the snake, and it crawled across the fence into the grass; notwithstanding, the birds flew over the fence into the grass also, and appeared to be bewitched to flutter around their charmer, and it was not until an attempt was made to kill the snake that the birds would avail themselves of their wings and fly to a forest one hundred rods distant.

The movements of the birds while around the snake seemed to be voluntary, and without the least constraint; nor did they utter any distressing cries, or appear enraged, as I often have seen them when squirrels, hawks, and mischievous buys attempted to rob their nests or to catch their young ones; but they seemed to be drawn by some allurement or enticement, (and not by any constraining or provoking power;) indeed, I thoroughly searched all the fences and trees in the vicinity to find some nest or young birds, but could find none.

What this fascinating power is, whether it be the look, or effluvium, or the singing by the vibrations of the tail of the snake, or

New Series. Vol. 2. No. 10. Oct. 1827.

$2 \mathrm{~S}$ any 